\title{
The Anticancer Activity of Sea Buckthorn [Elaeagnus rhamnoides (L.) A. Nelson]
}

\author{
Beata Olas*, Bartosz Skalski and Karolina Ulanowska \\ Department of General Biochemistry, Faculty of Biology and Environmental Protection, University of Lodz, Lodz, Poland
}

\section{OPEN ACCESS}

Edited by:

Suzie Chen,

Rutgers University, The State

University of New Jersey,

United States

Reviewed by:

Frank Arfuso,

Curtin University, Australia

Brian A. Wall,

Rutgers University, The State University of New Jersey, United States

*Correspondence: Beata Olas

beata.olas@biol.uni.lodz.pl

Specialty section: This article was submitted to Cancer Molecular Targets and Therapeutics,

a section of the journal

Frontiers in Pharmacology

Received: 24 January 2018 Accepted: 01 March 2018 Published: 15 March 2018

Citation:

Olas B, Skalski B and Ulanowska K (2018) The Anticancer Activity of Sea Buckthorn [Elaeagnus rhamnoides (L.) A. Nelson]. Front. Pharmacol. 9:232. doi: 10.3389/fphar.2018.00232
Various parts of sea buckthorn [Elaeagnus rhamnoides (L.) A. Nelson], particularly the berries, known also as seaberries, or Siberian pineapples, are characterized by a unique composition of bioactive compounds: phenolic compounds, vitamins (especially vitamin C), unsaturated fatty acids, and phytosterols such as beta-sitosterol. These berries, together with the juices, jams, and oils made from them, have a range of beneficial antioxidant, anti-inflammatory, and anticancer effects. This short review discusses whether sea buckthorn may represent a "golden mean" for the treatment of cancers: It has anti-proliferation properties and can induce apoptosis and stimulate the immune system, and sea buckthorn oil counteracts many side effects of chemotherapy by restoring kidney and liver function, increasing appetite, and keeping patients in general good health. Although the anticancer activity of sea buckthorn has been confirmed by many in vitro and animal in vivo studies, the treatment and prophylactic doses for humans are unknown. Therefore, greater attention should be paid to the development of well-controlled and high-quality clinical experiments in this area.

Keywords: Elaeagnus rhamnoides (L.) A. Nelson, sea buckthorn, cancer, antioxidant, phenolics, berry

\section{INTRODUCTION}

Sea buckthorn [Elaeagnus rhamnoides (L.) A. Nelson; Hippophae rhamnoides L. (old name)] is a member of the Elaeagnaceae. It is currently cultivated on a production scale, primarily in Russia and China, and in a growing number of varieties around the world (i.e., Finland, Germany, and Estonia).

Both in vitro and human and animal in vivo studies on sea buckthorn have found a range of bioactive chemicals in its leaves, roots, seeds, and berries, known as seaberry, or Siberian pineapple, as well as the oil extracted from them; these compounds exhibit a wide range of anti-inflammatory, anticancer, antioxidant, and anti-atherosclerotic activities (Zeb, 2006; Basu et al., 2007; Kumar et al., 2011; Suryakumar and Gupta, 2011; Xu et al., 2011; Christaki, 2012; Teleszko et al., 2015; Olas, 2016; Ulanowska et al., in press). Several trace elements and vitamins (especially A, C, and E), lipids, carotenoids, amino acids, unsaturated fatty acids, and phenolic compounds that are found in the berries are presented in Table 1 (Olas, 2016; Gradt et al., 2017; Ulanowska et al., in press). Their concentration in the berries depends on the climate, size, maturity of the plant, and the procedure used to process and store the plant material (Fatima et al., 2012; Malinowska and Olas, 2016). Gao et al. (2000) report changes in antioxidant properties, as well as other types of biological activity, in sea buckthorn berries during maturation, which were strongly correlated with the content of total phenolic compounds and ascorbic acid. Moreover, the antioxidant activity of the lipophilic extract increased significantly and corresponded to the increase in total carotenoid content. 
A wealth of healthy ingredients are found not only in the raw fruits, but also in a variety of preparations such as jams, juices, marmalades, or tinctures. Sea buckthorn berries can be also used to make pies and liquors ( $\mathrm{Li}$ and $\mathrm{Hu}, 2015)$. $\mathrm{Hu}$ (2005) reports that sea buckthorn seed can be used to make oil and the leaves can used to make tea. While teas made from the seeds have laxative properties and help weight loss, infusions of the leaves have antidiarrheal properties; in addition, fruit teas strengthen the immune system, and show activity against skin diseases (Sarwa, 2001; Frohne, 2010).

The positive and unique properties of sea buckthorn have been known since at least the VII Century BC (Suryakumar and Gupta, 2011; Li and $\mathrm{Hu}, 2015)$. The plant was used not only in natural medicine, but also veterinary medicine as a means of relieving helminthiasis in horses and providing them more mass and a beautiful, shiny coat. Currently, its products are used in many industries, especially the pharmaceutical, cosmetic, and food industries, but also as a decorative element, as firewood, or even as a tool for the rehabilitation of degraded areas. According to historical records, sea buckthorn was first used as a drug in China, and in more modern times, the plant was formally listed in the Chinese Pharmacopoeia in 1977 (The State of Pharmacopoeia Commission of PR China, 1977).

Modern studies have shown that the parts of sea buckthorn can serve as natural remedies for cardiovascular diseases, as well as diseases of the skin, liver, and stomach. The therapeutic potential of its bioactive compounds is demonstrated in Table 2. This review article summarizes the current knowledge concerning the different organs of sea buckthorn, and discusses whether they may represent a "golden mean" for the treatment of cancer. It is important to note that the source information for this paper is derived not only from in vitro models, but also in vivo models.

\section{ANTICANCER ACTIVITY OF SEA BUCKTHORN}

A number of phytopharmaceuticals, particularly such phenolic compounds as proanthocyanidins, curcumin, and resveratrol, have been found to offer significant benefits in cancer chemoprevention (Barrett, 1993; Bagchi and Preuss, 2004; Bagchi et al., 2014; Shanmugam et al., 2015; Ko et al., 2017) and radiotherapy (Cetin et al., 2008). It is well-documented that higher dietary intakes of phenolic compounds, especially procyanidins and flavonoids are associated with a lower risk of cancer (Barrett, 1993; Bagchi and Preuss, 2004; Duthie et al., 2006; Zafra-Stone et al., 2007; Cetin et al., 2008; Seeram, 2008; Bagchi et al., 2014; Chen et al., 2014; Wang et al., 2014; Giampieri et al., 2016; Kristo et al., 2016). Sea buckthorn possesses a wide range of biological and pharmacological activities, including anticancer properties. Although the molecular mechanisms

\footnotetext{
Abbreviations: Bax, the pro-apoptotic protein Bcl-2-associated X, FAS, fatty acid synthase; GA, gallic acid; HRWP-A, a water-soluble homogenous polysaccharide; IRF-1; interferon regulatory factor-1; LLC, Lewis lung carcinoma; NFKB, nuclear factor kappa-light-chain-enhancer of activated B cells; RH-3, whole extract of fresh sea buckthorn berries; TNF, tumor necrosis factor.
}

TABLE 1 | The chemical composition of individual parts of the sea buckthorn (44; modified).

\begin{tabular}{|c|c|}
\hline Part of sea buckthorn & Chemical composition \\
\hline Fruits (berries) & $\begin{array}{l}\text { Vitamins (C, E, B, } \mathrm{K}_{1}, \mathrm{D}, \mathrm{A} \text {, folic acid) } \\
\text { Macro and trace elements (potassium, magnesium, } \\
\text { calcium, iron, sodium, manganese, zinc, copper, nickel) } \\
\text { Carotenoids } \\
\text { Phenolic compounds } \\
\text { Lipids } \\
\text { Amino acids } \\
\text { Organic acids } \\
\text { Proteins } \\
\text { Sugars } \\
\text { Pectins }\end{array}$ \\
\hline Leaves & $\begin{array}{l}\text { Vitamins (E, folic acid) } \\
\text { Calcium, magnesium, potassium } \\
\text { Carotenoids } \\
\text { Phenolic compounds } \\
\text { Amino acids } \\
\text { Chlorophyll } \\
\text { Proteins } \\
\text { Pectins }\end{array}$ \\
\hline Seeds & $\begin{array}{l}\text { Carotenoids } \\
\text { Phenolic compounds } \\
\text { Lipids } \\
\text { Proteins }\end{array}$ \\
\hline Roots & $\begin{array}{l}\text { Carotenoids } \\
\text { Phenolic compounds } \\
\text { Lipids } \\
\text { Proteins }\end{array}$ \\
\hline Bark & Phenolic compounds \\
\hline
\end{tabular}

underlying them remain unclear, these compounds are known to be present in different organs and their products, especially in the juice and oil (Xu et al., 2011). The antitumor activity of sea buckthorn can be attributed to antioxidant compounds, particularly phenolic compounds such as flavonoids, including kaempferol, quercetin, and isorhamnetin; these protect cells from oxidative damage that can lead to genetic mutation and to cancer (Christaki, 2012).

\section{In Vitro Studies}

Various in vitro studies have demonstrated that sea buckthorn has anticancer activity. For example, Zhang et al. (2005) investigated changes in the expression of apoptosis-related genes in the human breast carcinoma cell line Bcap-37 induced by flavonoids from sea buckthorn seed. Their bioinformatics analysis found that the expression of 32 analyzed genes, including CTNNB1, IGFBP4, GADD34, and caspase 3, associated with the apoptosis of Bcap-37 cells, was influenced by flavonoid treatment.

Teng et al. (2006) found that isorhamnetin ( $3^{\prime}$-methoxy3,4'5,7-tetra hydroxyl flavone; a flavonoid isolated from sea buckthorn) has cytotoxic effects against human hepatocellular carcinoma cells (BEL-7402), with an $\mathrm{IC}_{50}$ of about $75 \mu \mathrm{g} / \mathrm{ml}$ after 72-h treatment. Li et al. (2015) also found isorhamnetin 
TABLE 2 | Sea buckthorn bioactive compounds and their therapeutic effects (44; modified).

\begin{tabular}{|c|c|}
\hline Bioactive compound & Therapeutic effect \\
\hline Tocopherol & $\begin{array}{l}\text { Antioxidant } \\
\text { Analgesic action } \\
\text { Protection against degenerative changes, thrombosis, } \\
\text { and muscle cramps }\end{array}$ \\
\hline Carotenoids & $\begin{array}{l}\text { Antioxidant } \\
\text { Involved in the synthesis of collagen } \\
\text { Protection and restoration of the mucous membranes } \\
\text { and epithelia } \\
\text { Enhancing the immune system }\end{array}$ \\
\hline Phytosterols & $\begin{array}{l}\text { Anti-atherosclerotic action, anti-inflammatory and } \\
\text { antibacterial properties } \\
\text { The prophylaxis and treatment of } \\
\text { hypercholesterolemia-induced cardiovascular disorders } \\
\text { by lowering serum cholesterol concentrations } \\
\text { Reducing the risk of stomach ulcers }\end{array}$ \\
\hline Unsaturated fatty acids & $\begin{array}{l}\text { Protecting against cerebrovascular and cardiovascular } \\
\text { disorders } \\
\text { Stimulating the immune system } \\
\text { Promoting cognitive function and bone health. } \\
\text { A positive effect on such neurological disorders as } \\
\text { depression, schizophrenia, and Alzheimer's disease }\end{array}$ \\
\hline Organic acids & $\begin{array}{l}\text { Acceleration of wound healing } \\
\text { Protecting against cerebrovascular and cardiovascular } \\
\text { disorders }\end{array}$ \\
\hline Vitamin C & $\begin{array}{l}\text { Antioxidant } \\
\text { Involved in the synthesis of collagen } \\
\text { Maintaining correct cell membrane integrity }\end{array}$ \\
\hline Vitamin K & $\begin{array}{l}\text { Prevention of bleeding } \\
\text { Reducing the risk of stomach ulcers } \\
\text { Assisting the reconstruction of skin damage }\end{array}$ \\
\hline Phenolic compounds & $\begin{array}{l}\text { Antioxidant } \\
\text { Reducing the risk of cardiovascular disease } \\
\text { Involved in regulating heart rhythm } \\
\text { Prevention of tumors } \\
\text { Alleviating the symptoms of aging }\end{array}$ \\
\hline
\end{tabular}

to have anti-proliferation effects on lung cancer cells in vitro when applied at concentrations ranging from 10 to $320 \mu \mathrm{g} / \mathrm{ml}$, and in vivo in C57BL/6 mice when administrated orally (50 $\mathrm{mg} / \mathrm{kg} / \mathrm{d}$ ) for 7 days. The authors suggest that the mechanism of isorhamnetin action may involve the apoptosis of cells induced by the down-regulation of oncogenes and up-regulation of apoptotic genes. Other observations showed that isorhamnetin suppresses the proliferation of cells from the human colorectal cancer cell lines (HT-29, HCT 116, and SW480), induces cell cycle arrest at the G2/M phase, and suppresses cell proliferation by inhibiting the PI3K-Akt-mTOR pathway. In addition, isorhamnetin reduced the phosphorylation levels of Akt (Ser473), phosph-p70S6 kinase, and phosph-4E-BP1 (t37/46) protein, and enhanced the expression of cyclin B1 protein at concentrations of 20 and $40 \mu \mathrm{M}$ (Li et al., 2014).
In a study on MDA-MB-231 human breast cancer cells, Wang et al. (2014) noted sea buckthorn procyanidins isolated from the seeds to have inhibitory effects on fatty acid synthase (FAS): a key enzyme for de novo long-chain fatty acid biosynthesis, high levels of which are found in cancer cells. This inhibition was dose-dependent at concentrations ranging from 0 to $0.14 \mu \mathrm{g} / \mathrm{ml}$. A concentration of $0.087 \mu \mathrm{g} / \mathrm{ml}$ inhibited $50 \%$ of FAS activity. Moreover, cell growth was suppressed by treatment with sea buckthorn procyanidins at concentrations between 10 and $60 \mu \mathrm{g} / \mathrm{ml}$. In addition, the tested procyanidins were found to induce cell apoptosis in a dose-dependent manner. The authors suggest that these procyanidins can induce MDA-MB-231 cell apoptosis by inhibiting intracellular FAS activity.

Olsson et al. (2004) compared the effect of 10 different extracts of fruits and berries, including sea buckthorn berries, on the proliferation of HT29 semi-colon cancer cells and MCF-7 breast cancer cells. They observed that sea buckthorn had the highest inhibition effect for the proliferation of HT29 and MCF-7 cells at its two highest administered concentrations ( 0.25 and $0.5 \%$ ). The authors suggest that the inhibition of cancer cell proliferation was correlated with concentrations of carotenoids and vitamin C. Moreover, they propose the presence of a synergistic action between carotenoids, vitamin C, and anthocyanins. In addition, McDougall et al. (2008) note that sea buckthorn berry extract possessed slightly antiproliferative effects against cervical and a semi-colon cancer cells grown in vitro.

Boivin et al. (2007) determined the antiproliferative activity of the juices of 13 types of berries, including sea buckthorn, at concentrations of $10-50 \mu \mathrm{g} / \mathrm{ml}$ against five cancer cell lines in vitro: AGS-stomach adenocarcinoma, ACF-7-mammary gland adenocarcinoma, PC-3-prostatic adenocarcinoma, Caco2-colorectal adenocarcinoma, and MDA-MB-231-mammary gland adenocarcinoma. It was found that sea buckthorn berry juice, like blackberry and black chokeberry juices, had antiproliferative properties. However, no correlation was found between the anti-proliferative properties of the berry juices and their antioxidant capacity, and the inhibition of cancer cell proliferation by the juices did not involve caspase-dependent apoptosis. Despite this, suppression of tumor necrosis factor (TNF)-induced activation of nuclear factor kappa-light-chainenhancer of activated B cells (NFKB) was observed.

Recently, Guo et al. (2017) studied the phytochemical composition of the berries of four different subspecies of sea buckthorn, as well as their antioxidant and antiproliferative properties against HepG2 human liver cancer cells in vitro: H. rhamnoides L. subsp. sinensis (Sinensis), H. rhamnoides L. subsp. yunnanensis (Yunnanensis), H. rhamnoides $\mathrm{L}$. subsp. mongolica (Mongolica), and H. rhamnoides L. subsp. turkestanica (Turkestanica). Of these subspecies, H. rhamnoides L. subsp. sinensis demonstrated the highest total phenolic content [about $39 \mathrm{mg}$ gallic acid (GA) equiv./g dry weight] and corresponding total antioxidant activity, while the greatest cellular antioxidant and antiproliferative properties were observed in $H$. rhamnoides L. subsp. yunnanensis. These properties were attributed to the action of phenolic acids and flavonoid aglycones. 
Zhamanbaeva et al. (2014) studied the effects of ethanol extract from sea buckthorn leaves on the growth and differentiation of human acute myeloid leukemia cells (KG-1a, HL60, and U937). Although a plant extract was found to inhibit cell growth according to cell strain and extract dose, the study does not identify the chemical content of the tested extract. They used three concentrations of the extract: 25,50 , and $100 \mu \mathrm{g} / \mathrm{ml}$. The findings suggest that the antiproliferative effect of sea buckthorn extract on acute myeloid leukemia cells was partially determined by activation of the $S$ phase checkpoint, which probably led to deceleration of the cell cycle and induction of apoptosis.

Elsewhere, Zhamanbayeva et al. (2016) studied the antiproliferative and differentiation-enhancing activity of various plant extracts $(10-100 \mu \mathrm{g} / \mathrm{ml})$, including water-ethanol extract from leaves of sea buckthorn: it was found to have a total polyphenol content of approximately $46 \mathrm{mg}$ GA equivalent/g dried extract, total flavonoid content of approximately $23 \mathrm{mg}$ quercetin equivalent/g dried extract. The authors observed that the tested extracts, including sea buckthorn extract, reduced the growth and viability of acute myeloid leukemia cells; in addition, at non-cytotoxic doses, they also potentiated cell differentiation induced by a low concentration of 1 1 ,25-dihydroxyvitamin $\mathrm{D}_{3}$, in a manner dependent on cell type. Moreover, the tested extracts strongly inhibited microsomal lipid peroxidation and protected normal erythrocytes against hypo-osmotic shock.

A recent study by Kim et al. (2017) proposes that sea buckthorn leaf extract, containing about $70 \mathrm{mg} / \mathrm{g}$ total phenolic compounds and about $460 \mu \mathrm{g} / \mathrm{g}$ catechin, may inhibit the rapid proliferation of rat C6 glioma cells when administered at 0.62 , 6.2 , and $62 \mu \mathrm{g} / \mathrm{ml}$, probably by inducing the early events of apoptosis. The authors also suggest that the reduction of C6 glioma cell proliferation and viability following administration of the plant extract was accompanied by a decrease in the production of reactive oxygen species, which are critical for the proliferation of tumor cells. Moreover, sea buckthorn not only upregulated the expression of the pro-apoptotic protein Bcl-2associated $\mathrm{X}$ (Bax), but also promoted its localization in the nucleus.

Various studies report that sea buckthorn oil also possesses anti-tumor properties. This oil can be incorporated in capsules, gelatin, and oral liquids (Yang and Kallio, 2002). Moreover, toxicity studies report no adverse effects in subjects administered with sea buckthorn oil (Upadhyay et al., 2009). Kumar et al. (2011) indicate that sea buckthorn oil plays an important role in cancer therapy, including chemotherapy and radiotherapy, and that taking sea buckthorn oil may help counteract many side effects or treatment, restore kidney and liver function, increase appetite, and generally keep patients in good health. Wang et al. (1989) observed that seed oil retarded tumor growth by $3-50 \%$. Zhang et al. (Zhang, 1989) demonstrated that injection of seed oil $(1.59 \mathrm{~g} / \mathrm{kg}$ body weight) significantly inhibited the growth rate of transplanted melanoma $\left(\mathrm{B}_{16}\right)$ and sarcoma $\left(\mathrm{S}_{180}\right)$ tumors in mice. Wu et al. (1989) attribute the protective effect of sea buckthorn seed oil against cervical cancer to the presence of vitamins A and E. Finally, Sun et al. (2003) note that flavonoids from oil extracted from sea buckthorn seeds exert an inhibitory action on the liver cancer cell line BEL-7402 by inducing apoptosis.

The seeds and berry pulp of sea buckthorn contains various other bioactive compounds, including unsaturated fatty acids and phytosterols. It is known that unsaturated fatty acids have a multidirectional influence on human health, for example, by stimulating the immune system. In addition, phytosterols have anticancer properties (Sajfratova et al., 2010; Dulf, 2012). More details about the composition and beneficial health aspects of sea buckthorn oil are given by Olas (2018). The effect of sea buckthorn on cancer cells in different in vitro models is described in Table 3.

\section{In Vivo Studies}

Sea buckthorn has been found to have anticancer properties in both in vitro and in vivo studies on animal models. A study of the chemopreventive action of sea buckthorn fruits by Padmavathi et al. (2005) found them to inhibit dimethylobenzenoantraceninduced skin papillomagenesis in mice. The authors suggest that inhibition of carcinogenesis may be attributed to the concomitant induction of phase II enzymes, i.e., glutathione S-transferase, glutathione peroxidase, catalase, superoxide dismutase, and glutathione reductase in mouse liver. Moreover, the authors also suggest that the anticancer action of sea buckthorn fruits may be based on its enhancement of the DNA-binding activity of interferon regulatory factor-1 (IRF-1), a known antioncogenic transcription factor causing growth suppression and apoptosis.

Nersesyan and Muradyan (2004) report that sea buckthorn juice protects mice against the genotoxic action of cisplatin: a well-known anticancer drug which also is very toxic to normal cells. Sea buckthorn juice $(300 \mathrm{ml})$ prepared ex tempore was given to mice by gavage for periods of 5 or 10 days. $3 \mathrm{~h}$ after the last gavage, mice received cisplatin at concentrations of 1.2 or $2.4 \mathrm{mg} / \mathrm{kg}$.

Yasukawa et al. (2009) found 70\% ethanol extract of sea buckthorn branches ( $1 \mathrm{mg}$ of plant extract/mouse) to have antitumor properties in an in vivo two-stage carcinogenesis test with two groups of 15 mice; 7,12-dimethylbenz[a]anthracene as an indicator, and 12-O-tetracecanoyl-phorbol-13-acetate as a promotor. Of the three phenolic compounds (catechin, gallocatechin, and epigallocatechin) and the triterpenoid ursolic acid isolated from the extract, epigallocatechin, and ursolic acid were found to be the most active.

Wang et al. (2015) found that not only the phenolic compounds or phenolic extracts/fractions of sea buckthorn have anticancer properties: HRWP-A, a water-soluble homogenous polysaccharide with repeating units of $(1 \rightarrow 4)$ $\beta$-D-galactopyranosyluronic residues, of which $85.2 \%$ are esterified with methyl groups, also demonstrates anticancer and immunostimulating activities in vivo. An antitumor activity assay demonstrated that HRWP-A could significantly inhibit Lewis lung carcinoma (LLC) growth in tumor-bearing mice. In addition, this compound enhanced lymphocyte proliferation, augmented macrophage activities, and promoted natural killer cell activity in tumor-bearing mice. The authors used three different doses of polysaccharide (50, 100, and $200 \mathrm{mg} / \mathrm{kg}$ ), 
TABLE 3 | The effect of sea buckthorn on cancer cells in in vitro models.

\begin{tabular}{|c|c|c|c|c|}
\hline $\begin{array}{l}\text { Extract/chemical } \\
\text { compound or other form } \\
\text { obtained from sea } \\
\text { buckthorn }\end{array}$ & Cancer cells & Concentration & Effect & Reference \\
\hline \multicolumn{5}{|c|}{ EXTRACT OR OTHER FORM OBTAINED FROM SEA BUCKTHORN } \\
\hline Berry juice & $\begin{array}{l}\text { Cell lines of breast cancer, } \\
\text { prostate, stomach, and a } \\
\text { semi-colon }\end{array}$ & $10-50 \mu \mathrm{l} / \mathrm{ml}$ of medium & $\begin{array}{l}\text { Inhibition of tumor cell proliferation of } \\
\text { all tested lines }\end{array}$ & Boivin et al., 2007 \\
\hline $\begin{array}{l}\text { Extract from berries in } \\
\text { different solvents }\end{array}$ & $\begin{array}{l}\text { Cancer cells of a semi-colon and } \\
\text { liver }\end{array}$ & $<0.1-2 \%(v / v)$ of medium & $\begin{array}{l}\text { Inhibition of tumor cell proliferation of } \\
\text { all tested lines; extract with ethyl } \\
\text { acetate also caused apoptosis of } \\
\text { these cells }\end{array}$ & Grey et al., 2010 \\
\hline $\begin{array}{l}\text { Ethanol-water extract from } \\
\text { berries }\end{array}$ & $\begin{array}{l}\text { Cancer cells of the breast and a } \\
\text { semi-colon }\end{array}$ & $\begin{array}{l}0.025-0.5 \% \text { the dry weight } \\
\text { in medium }\end{array}$ & $\begin{array}{l}\text { Inhibition of tumor cell proliferation of } \\
\text { all tested lines }\end{array}$ & Olsson et al., 2004 \\
\hline $\begin{array}{l}\text { Ethanol-water extract from } \\
\text { berries }\end{array}$ & Acute myeloid leukemia cells & $10-100 \mu \mathrm{g} / \mathrm{ml}$ & Anti-proliferative action & Zhamanbayeva et al., 2016 \\
\hline Ethanol extract from berries & Acute myeloid leukemia cells & 25,50, and $100 \mu \mathrm{g} / \mathrm{ml}$ & Anti-proliferative action & Zhamanbaeva et al., 2014 \\
\hline Leaf extract & C6 glioma cells & $0.62,6.2$, and $62 \mu \mathrm{g} / \mathrm{ml}$ & Anti-proliferative action & Kim et al., 2017 \\
\hline $\begin{array}{l}\text { Isorhamnetin isolated from } \\
\text { berries of sea buckthorn }\end{array}$ & Cancer cells of the liver & $\begin{array}{l}25-300 \mu \mathrm{g} / \mathrm{ml} \text { of medium } \\
\left(\mathrm{IC}_{50}=75 \mu \mathrm{g} / \mathrm{ml}\right)\end{array}$ & $\begin{array}{l}\text { Cytotoxicity against cancer cells-a } \\
\text { decrease in their vitality, fragmentation } \\
\text { and chromatin condensation }\end{array}$ & Teng et al., 2006 \\
\hline $\begin{array}{l}\text { Isorhamnetin isolated from } \\
\text { berries of sea buckthorn }\end{array}$ & Lung cancer cells & $10-320 \mu \mathrm{g} / \mathrm{ml}$ & Anti-proliferative action & Li et al., 2015 \\
\hline $\begin{array}{l}\text { Isorhamnetin isolated from } \\
\text { berries of sea buckthorn }\end{array}$ & Colorectal cancer cells & 20 and $40 \mu \mathrm{M}$ & Anti-proliferative action & Li et al., 2014 \\
\hline $\begin{array}{l}\text { Procyanidins isolated from } \\
\text { seeds }\end{array}$ & Breast cancer cells & $10-60 \mu \mathrm{g} / \mathrm{ml}$ & Inducing apoptosis & Wang et al., 2014 \\
\hline
\end{tabular}

which were administrated intragastrically each day for 14 days.

\section{RADIOPROTECTIVE ABILITY OF SEA BUCKTHORN}

Due to its high content of biologically-active compounds and antioxidants, sea buckthorn is included in cancer therapy for its radioprotective activity, which has been demonstrated in a number of studies by Goel et al. (2002, 2003a,b, 2004, 2005). Agrawala and Goel (2002) found whole extract of fresh sea buckthorn berries to have protective properties (H. rhamnoidesRH-3; 25-35 mg/kg body wt), particularly for radiation-induced micronuclei in mouse bone marrow. In addition, Goel et al. (2002) found that RH-3 inhibited the Fenton reaction and radiation-mediated production of hydroxyl radicals in vitro.

Kumar et al. (2002) report that RH-3 inhibited DNA strand breaks induced by radiation and tertiary butyl hydroperoxide in a dose-dependent manner, as revealed by Comet assay. They also note a strong compaction of chromatin occurring at concentrations of 100 and $120 \mathrm{pg} / \mathrm{ml} \mathrm{RH}-3$ and above, which made the nuclei resistant to radiation, even at a dose of $1,000 \mathrm{~Gy}$. Goel et al. (2003a) report the protection of jejunal crypts by RH-3 against lethal whole body gamma irradiation (10 Gy), and that caspase-3 activity was also significantly lower in mice administered $\mathrm{RH}-3$ before irradiation as compared to irradiated controls. Interestingly, a radioprotective dose of RH-3 (30 mg/kg b.w.) induced significant DNA fragmentation (studied spectrofluorimetrically) in thymocytes in mice in vivo. In addition, sea buckthorn treatment before irradiation was found to enhance radiation-induced apoptosis in vivo (Goel et al., 2004). Goel et al. (2005) suggest also that pre-irradiation treatment of mice with $30 \mathrm{mg} / \mathrm{kg}$ sea buckthorn berry extract protects the functional integrity of mitochondria from radiation-induced oxidative stress. These experiments examined the levels of various biomarkers of oxidative stress, including superoxide anion, lipid peroxidation, and protein oxidation. Interestingly, $\mathrm{RH}-3$ was found to have immunostimulatory properties, which may play an important role in its radioprotective efficacy (Prakash et al., 2005).

\section{CONCLUSION}

Although many studies have confirmed the anticancer activity of sea buckthorn, its medicinal and prophylactic doses remain unknown, and no clinical trials have yet been performed: only in vitro or in vivo studies involving experimental animals. It is known that sea buckthorn may participate in the prevention and treatment of cancer; it also accelerates the return to health of patients receiving chemotherapy by significantly improving the performance of the immune system and relieves hematological damage. 


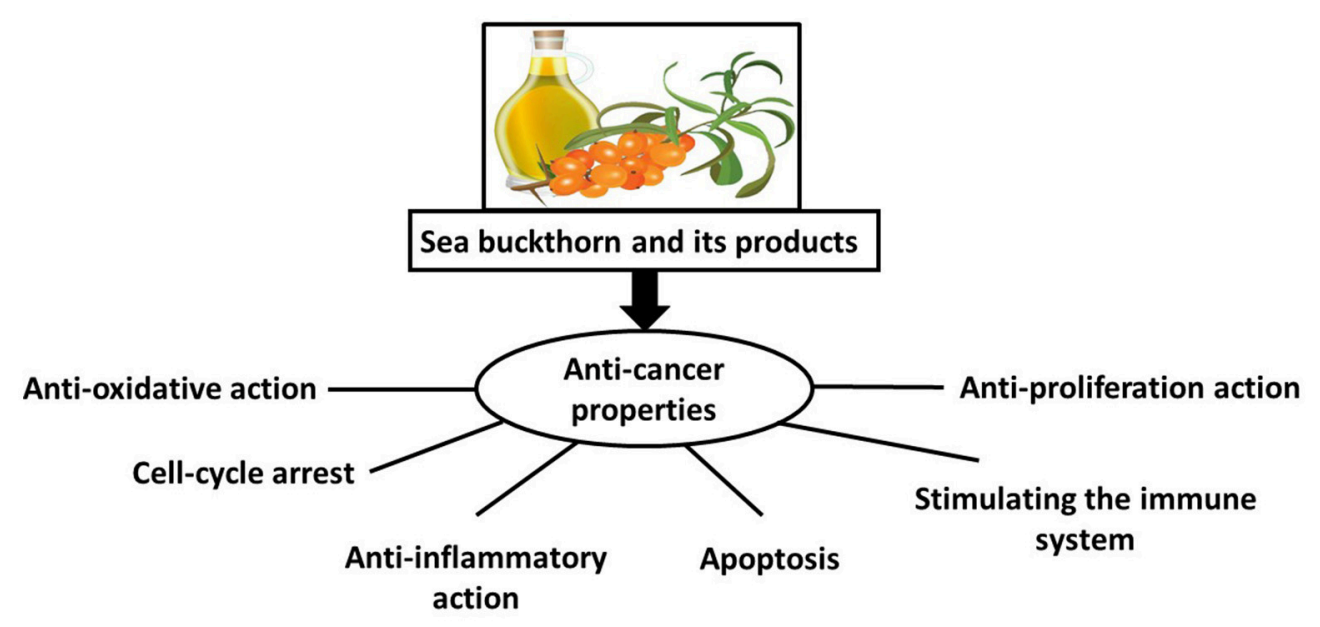

FIGURE 1 | Hypothetical mechanisms of action by which sea buckthorn may evoke chemopreventive and therapeutic responses against cancer.

The hypothetical mechanism by which sea buckthorn may exert its chemopreventive and therapeutic responses against cancer is presented in Figure 1. The bioactive substances in various parts of sea buckthorn have a range of properties, including antioxidant, anti-inflammatory, and anti-proliferative activities; they also induce apoptosis and strengthen the immune system; however, the molecular mechanisms remain unclear. Therefore, before sea buckthorn can be considered the "golden mean" for treatment of cancers, it requires further study in a range of high-quality studies.

\section{REFERENCES}

Agrawala, P. K., and Goel, H. (2002). Protective effect of RH-3 with special reference to radiation induced micronuclei in mouse bone marrow. Indian J. Exp. Biol. 40, 525-530.

Bagchi, D., and Preuss, H. G. (2004). Phytopharmaceuuticals in Cancer Chemoprevention, 1st Edn. Bocca Raton, FL: CRC Press.

Bagchi, D., Swaroop, A., Preuss, H., and Bagchi, M. (2014). Free radical scavenging, antioxidant and cancer chemoprevention by grape seed proanthocyanidin: an overview. Mutat. Res. 768, 69-73. doi: 10.1016/j.mrfmmm.2014.04.004

Barrett, J. C. (1993). Mechanisms of multistep carcinogenesis and carcinogen risk assessment. Environ. Health Perspect. 100, 9-20. doi: 10.1289/ehp. 931009

Basu, M., Prasad, R., Jayamurthy, P., Pal, K., Arumughan, C., and Sawhney, R. C. (2007). Anti-atherogenic effects of seabuckthorn (Hippophaea rhamnoides) seed oil, Phytomedicine 14, 770-777. doi: 10.1016/j.phymed.2007.03.018

Boivin, D., Blanchette, M., Barrette, S., Moghrabi, A., and Beliveau, R. (2007). Inhibition of cancer cell proliferation and suppression of TNF-induced activation of NFKB by edible berry juice. Anticancer Res. 27, 937-948.

Cetin, A., Kaynar, L., Kocyigit, I., Hacioglu, S., Saraymen, R., Ozturk, A., et al. (2008). The effect of grape seed extract on radiation-induced oxidative stress in the rat liver. Turk. J. Gastroenterol. 19, 92-98.

Chen, L., Xin, X., Yuan, Q., Su, D., and Liu, W. (2014). Phytochemical properties and antioxidant capacities of various colored berries. J. Sci. Food Agric. 94, 180-188. doi: 10.1002/jsfa.6216

Christaki, E. (2012). Hippophae rhamnoides L. (Sea Buckthorn): a potential source of nutraceuticals. Food Pub. Health 2, 69-72. doi: 10.5923/j.fph.20120203.02

Dulf, F. V. (2012). Fatty acids in berry lipids of six sea buckthorn (Hippophae rhamnoides L. subspecies carpatica) cultivars grown in Romania. Chem. Cent. J. 6, 1-12. doi: 10.1186/1752-153X-6-106

\section{AUTHOR CONTRIBUTIONS}

All authors (BO, BS, KU) listed have made a substantial, direct and intellectual contribution to the work, and approved it for publication.

\section{ACKNOWLEDGMENTS}

This work was supported by National Science Centre, Poland 2015/19/B/NZ9/03164.

Duthie, S., Jenkinson, A., Crozier, A., Mullen, W., Pirie, L., Kyle, J., et al. (2006). The effects of cranberry juice consumptions on antioxidant status and biomarkers relating to heart disease and cancer in healthy human volunteers. Eur. J. Nutr. 45, 113-122. doi: 10.1007/s00394-005-0572-9

Fatima, T., Snyder, C., Schroeder, W., Cram, D., Datla, R., Wishart, D., et al. (2012). Fatty acid composition of developing sea buckthorn (Hippophae rhamnoides L.) berry and the transcriptome of the mature seed. PLOS ONE 7:e34099. doi: 10.1371/journal.pone.0034099

Frohne, D. (2010). Leksykon Roślin Leczniczych MedPharm. Wroclaw, 276.

Gao, X., Ohlander, M., Jeppsson, N., Bjork, L., and Trajkovski, V. (2000). Changes in antioxidant effects and their relationship to phytonutrients in fruits of sea buckthorn (Hippophae rhamnoides L.) during maturation, J. Agric. Food Chem. 48, 1485-1490. doi: 10.1021/jf991072g

Giampieri, F., Alvarez-Suarez, J., Gasparrini, M., Forbes-Hernandez, T., Afrin, S., Bompadre, S., et al. (2016). Strawberry consumption alleviates doxorubicininduced toxicity by suppressing oxidative stress. Food Chem. Toxicol. 94, 128-127. doi: 10.1016/j.fct.2016.06.003

Goel, H. C., Gupta, D., Gupta, S., Garg, A. P., and Bala, M. (2005). Protection of mitochondrial system by Hippophae rhamnoides L. against radiationinduced oxidative damage in mice. J. Pharm. Pharmacol. 57, 135-143. doi: 10.1211/0022357055218

Goel, H. C., Indraghanti, P., Samanta, N., and Ranaz, S. V. (2004). Induction of apoptosis in thymocytes by Hippophae rhamnoides: implications in radioprotection. J. Environ. Pathol. Toxicol. Oncol. 23, 123-137. doi: 10.1615/JEnvPathToxOncol.v23.i2.50

Goel, H. C., Kumar, I. P., Samanta, N., and Rana, S. V. (2003a). Induction of DNAprotein cross-links by Hippophae rhamnoides: implications in radioprotection and cytotoxicity. Mol. Cell Biochem. 245, 57-67. doi: 10.1023/A:1022809625826

Goel, H. C., Prasad, J., Singh, S., Sagar, R. K., Kumar, I. P., and Sinha, A. K. (2002). Radioprotection by a herbal preparation of Hippophae rhamnoides, 
RH-3, against whole body lethal irradiation in mice. Phytomedicine 9, 15-25. doi: 10.1078/0944-7113-00077

Goel, H. C., Salin, C., and Prakash, H. (2003b). Protection of jejunal crypts by RH3 (a preparation of Hippophae rhamnoides) against lethal whole body gamma irradiation. Phytother Res. 17, 222-226. doi: 10.1002/ptr.1109

Gradt, I., Kuhn, S., Morsel, J., and Zvaigzne, G. (2017). Chemical composition of sea buckthorn leaves, branches and bark. Proc. Natl. Acad. Sci. U.S.A. 3, 211-216. doi: 10.1515/prolas-2017-0035

Grey, C., Widen, C., Adlercreutz, P., Rumpunen, K., and Duan, R. (2010), Antiproliferative effects of sea buckthorn (Hippophae rhamnoides L.) extracts on human colon and liver cancer cell lines. Food Chem. 120, 1004-1010. doi: 10.1016/j.foodchem.2009.11.039

Guo, R., Guo, X., Li, T., Fu, X., and Liu, R. (2017). Comparative assessment of phytochemical profiles, antioxidant and antiproliferative activities of Sea buckthorn (Hippophae rhamnoides L.). Food Chem. 221, 997-1003. doi: 10.1016/j.foodchem.2016.11.063

Hu, S. (2005). “Hippophae rhamnoides L. - Sea buckthorn, shaji," in Food Plants of China (The Chinese University Press), 572.

Kim, S., Hwang, E., Yi, S., Song, K., Lee, H., Heo, T., et al. (2017). Sea buckthorn leaf extracts inhibits glioma cell growth by reducing reactive oxygen species and promoting apoptosis. Appl. Biochem. Biotechnol. 182, 1663-1674. doi: 10.1007/s12010-017-2425-4

Ko, J. H., Sethi, G., Um, J. Y., Shanmugam, M. K., Arfuso, F., Kumar, A., et al. (2017). The role of resveratrol in cancer therapy. J. Mol. Sci. 18:2589. doi: $10.3390 /$ ijms18122589

Kristo, A., Klimis-Zacas, D., and Sikaliidis, A. (2016). Protective role of dietary berries in cancer, Antioxidants 5:37. doi: 10.3390/antiox5040037

Kumar, I. P., Namita, S., and Goel, H. C. (2002). Modulation of chromatin organization by RH-3, a preparation of Hippophae rhamnoides, a possible role in radioprotection. Mol. Cell. Biochem. 238, 1-9. doi: 10.1023/A:1019905 211392

Kumar, R., Kumar, G. P., Chaurasia, O. P., and Singh, S. (2011). Phytochemical and pharmacological profile of seabuckthorn oil: a review. Res. J. Med. Plant 5, 491-499. doi: 10.3923/rjmp.2011.491.499

Li, C. H., Yang, X., Chen, C. H., Cai, S., and Hu, J. (2014). Isorhamnetin suppresses colon cancer cell growth through the PI3K-Akt-mTOR pathway. Mol. Med. Rep. 9, 935-940. doi: 10.3892/mmr.2014.1886

Li, Q., Ren, F., Yang, C., Zhou, L., Liu, Y., Xiao, J., et al. (2015). Anti-proliferation effects of isorhamnetin on lung cancer cells in vitro and in vivo. Asian Pac. J. Cancer Prev. 16, 3035-3042. doi: 10.7314/APJCP.2015.16.7.3035

Li, Y., and Hu, C. (2015). "Hippophae rhamnoides L. (Shaji, Common Seabuckthorn)," in Dietary Chinese Herbs: Chemistry, Pharmacology and Clinical Evidence, eds Y. Liu, Z. Wang, and J. Zhang (Vienna: Springer Science and Business Media), 411.

Malinowska, P., and Olas, B. (2016). Sea buckthorn - valuable plant for health. Kosmos 2, 285-292. doi: 10.1186/s12944-017-0469-7

McDougall, G., Ross, H., Ikeji, M., and Stewart, D. (2008). Berry extracts exert different antiproliferative effects against cervical and colon cancer cells grown in vitro. J. Agric. Food Chem. 56, 3016-3023. doi: 10.1021/jf073469n

Nersesyan, A., and Muradyan, R. (2004). Sea-buckthorn juice protects mice against genotoxic action of cisplastin. Exp. Oncol. 26, 153-155.

Olas, B. (2016). Sea buckthorn as a source of important bioactive compounds in cardiovascular diseases. Food Chem. Toxicol. 97, 199-204. doi: $10.1016 /$ j.fct. 2016.09 .008

Olas, B. (2018). The composition and beneficial health aspects of sea buckthorn (Hippophae rhamnoides L.) oil. J. Ethnopharm. 213, 183-190. doi: 10.1016/j.jep.2017.11.022

Olsson, M., Gustavsson, K., Andersson, S., Nilsson, A., and Duan, R. (2004). Inhibition of cancer cell proliferation in vitro by fruit and berry extracts and correlations with antioxidant levels. J. Agric. Food Chem. 52, 7264-7271. doi: 10.1021/jf030479p

Padmavathi, B., Upreti, M., Singh, V., Rao, A. R., Singh, R. P., and Rath, P. C. (2005). Chemoprevention by Hippophae rhamnoides: effects on tumorigenesis, phase II and antioxidant enzymes, and IRF-1 transcription factor. Nutr. Cancer 51, 59-67. doi: 10.1207/s15327914nc5101 9

Prakash, H., Bala, M., Ali, A., and Goel, H. C. (2005). Modification of gamma radiation induced response of peritoneal macrophages and splenocytes by
Hippophae rhamnoides (RH-3) in mice. J. Pharm. Pharmacol. 57, 1065-1072. doi: $10.1211 / 0022357056668$

Sajfratova, M., Lickova, I., Wimmerova, M., Sovova, H., and Wimmer, Z. (2010). $\beta$-Sitosterol: supercritical carbon dioxide extraction from sea buckthorn (Hippophae rhamnoides L.) seeds. Int. J. Mol. Sci. 11, 1842-1850. doi: 10.3390/ijms11041842

Sarwa, A. (2001). Wielki Leksykon Roślin Leczniczych. Warszawa: Książka i Wiedza. Seeram, N. (2008). Berry fruits: compositional elements, biochemical activities, and the impact of their intake on human health, performance, and disease. J. Agric. Food Chem. 56, 627-629. doi: 10.1021/jf071988k

Shanmugam, M., Rane, G., Mathi, K. M., Arfuso, F., Chinnathambi, A., Zayed, M. E., et al. (2015). The multifaceted role of curcumin in cancer prevention and treatment. Molecules 20, 2728-2769. doi: 10.3390/molecules 20022728

Sun, B., Zhang, P., Qu, W., Zhang, X., Zhuang, X., and Yang, H. (2003). Study on effect of flavonoids from oil-removed seeds of Hippophae rhamnoides on inducing apoptosis of human hepatoma cell. Zhong Yao Cai 26, 875-877.

Suryakumar, G., and Gupta, A. (2011). Medicinal and therapeutic potential of Sea buckthorn (Hippophae rhamnoides L.). J. Ethnopharmacol. 138, 268-278. doi: 10.1016/j.jep.2011.09.024

Teleszko, M., Wojdylo, A., Rudzinska, M., Oszmianski, J., and Golis, T. (2015). Analysis of lipophilic and hydrophilic bioactive compounds content in sea buckthorn (Hippophae rhamnoids L.) berries. J. Agric. Food Chem. 63, 4120-4129. doi: 10.1021/acs.jafc.5b00564

Teng, B., Lu, Y., Wang, Z., Tao, X., and Wei, D. (2006). In vitro anti-tumor activity of isorhamnetin isolated from Hippophaer rhamnoides L. against BEL-7402 cells. Pharm. Res. 54, 186-194. doi: 10.1016/j.phrs.2006.04.007

The State of Pharmacopoeia Commission of PR China (1977). Pharmacopeia of the People's Republic of China 1997, Beijing.

Ulanowska, K., Skalski, B., and Olas, B. (in press). Sea-buckthorn (Hippophae rhamnoides L.) as a source of compounds with antitumor and radioprotective activity. Postepy Hig. Med. Dosw.

Upadhyay, N. K., Kumar, R., Mandotra, S. K., Meena, R. M., Siddiqu, M. S., Sawhney, R. C., et al. (2009). Safety and wound healing efficacy of sea buckthorn (Hippophae rhamnoides L.) seed oil in experimental rats. Food Chem. Toxicol. 47, 1146-1153. doi: 10.1016/j.fct.2009.02.002

Wang, H., Gao, T., Du, Y., Yang, H., Wei, L., Bi, H., et al. (2015). Anticancer and immunostimulating activities of a novel homogalacturonan from Hippophae rhamnoides L. berry. Carbohydr. Polym. 131, 288-296. doi: 10.1016/j.carbpol.2015.06.021

Wang, H., Ge, H., and Zhi, J. (1989). “The components of unsaponifiable matters in sea buckthorn fruit and seed oil," in Proceedings first International Symposium on Sea Buckthorn (Xi'an), 81-90.

Wang, Y., Nie, F., Ouyang, J., and Wang, X. (2014). Inhibitory effects of sea buckthorn procyanidins on fatty acid synthase and MDA-MB-231 cells. Tumor Biol. 35, 9563-9569. doi: 10.1007/s13277-014-2233-1

Wu, A., Su, Y., Li, J., Liu, Q., Lu, J., Wei, X., et al. (1989). “The treatment of chronic cervicitis with Hippophae oil and its suppository (129 cases analysis)," in Proceedings first International Symposium on Sea Buckthorn, 404-406.

Xu, Y. J., Kaur, M., Dhillon, R. S., Tappia, P. S., and Dhalla, N. S. (2011). Health benefits of sea buckthorn for the prevention of cardiovascular diseases. J. Funct. Foods 3, 2-12. doi: 10.1016/j.jff.2011.01.001

Yang, B., and Kallio, H. (2002). Composition and physiological effects of sea buckthorn (Hippophae) lipids. Trends Food Sci. Technol. 13, 160-167. doi: 10.1016/S0924-2244(02)00136-X

Yasukawa, K., Kitanaka, S., Kawata, K., and Goto, K. (2009). Anti-tumor promoters phenolics and triterpenoid from Hippophae rhamnoides. Fitoterapia 80, 164-167. doi: 10.1016/j.fitote.2009.01.006

Zafra-Stone, S., Yasmin, T., Bagchi, M., Chatterjee, A., Vinson, J., and Bagchi, D. (2007). Berry anthocyanins as novel antioxidants in human health and disease prevention. Mol. Nutr. Food. Res. 51, 675-683. doi: 10.1002/mnfr.200700002

Zeb, A. (2006). Anticarcinogenic potential of lipids from hippophae evidence from the recent literature. Asian Pac. J. Cancer Prev. 7, 32-34.

Zhamanbaeva, G., Murzakhmetova, M., Tuleukhanov, S., and Danilenko, M. (2014). Antitumor activity of ethanol extract from Hippophae rhamnoides L. leaves towards human acute myeloid leukemia cells 
in vitro. Bull. Exp. Biol. Med. 158, 221-224. doi: 10.1007/s10517-0142734-3

Zhamanbayeva, G., Aralbayeva, A., Murzakhmetova, M., Tuleukhanov, S., and Danilenko, M. (2016). Cooperative antiproliferative and differentiationenhancing activity of medicinal plant extracts in acute myeloid leukemia cells. Biomed. Pharmacother. 82, 80-89. doi: 10.1016/j.biopha.2016. 04.062

Zhang, P. (1989). Anti-cancer activities of sea buckthorn seed oil and its effects on the weight of immune organs Seabuckthorn 2, 31-34.

Zhang, P., Mao, Y. C., Sun, B., Qian, M., and Qu, W. J. (2005). Changes in apoptosis-related genes expression profile in human breast carcinoma cell line Bcap-37 induced by flavonoids from seed residues of Hippophae rhamnoides. L. Ai Zheng 24, 454-460.
Conflict of Interest Statement: The authors declare that the research was conducted in the absence of any commercial or financial relationships that could be construed as a potential conflict of interest.

The reviewer BW and handling Editor declared their shared affiliation.

Copyright (c) 2018 Olas, Skalski and Ulanowska. This is an open-access article distributed under the terms of the Creative Commons Attribution License (CC $B Y)$. The use, distribution or reproduction in other forums is permitted, provided the original author(s) and the copyright owner are credited and that the original publication in this journal is cited, in accordance with accepted academic practice. No use, distribution or reproduction is permitted which does not comply with these terms. 